\title{
Civil Liberties and Public Good: Detention of Tuberculous Patients and the Public Health Act 1984
}

\author{
RICHARD COKER*
}

On 30 August 1998, the Mail on Sunday, under the headline "TB refugee 'must be held in hospital" ", described the case of a Somalian man who had been "ordered by a court to remain in hospital for six months to prevent him spreading a highly infectious deadly disease". That disease was tuberculosis and a court order had been issued "after the man had twice staggered into Northwick Park Hospital in Harrow, North-West London, for treatment but left without trace. He failed to take prescribed treatment and his condition rapidly deteriorated, forcing him to return to hospital a third time."

As was noted by the executive director of Brent and Harrow Health Authority, "there comes a time when you must clearly draw a balance between civil liberties and public good". 2 That balance, as I shall show, has been redrawn in legislation and public policy over the past seventy-five years as concerns over the threat posed by those with tuberculosis has waxed and waned.

Because no central records are kept, it is unclear how many individuals have been detained under legislation, but there are suggestions that more detention orders are being issued now than in earlier years, and that the duration of detention is, in some cases, considerably longer than previously. ${ }^{3}$ For example, the Ministry of Health noted, in 1958, that "the power [of detention] has not to our knowledge been invoked". Twenty-five years earlier, just a few years after the enactment of the 1925 Public Health Act, which first codified the authority to detain tuberculous individuals, Sir Arthur MacNalty, later to be Chief Medical officer, concluded that

. . . in practice local authorities have seldom found it necessary to take action under this Act. The majority of infectious persons suffering from tuberculosis are usually only too glad

* Richard Coker, MD, MSc, DFPHM, FRCP, Research Fellow, Public Health, London School of Hygiene and Tropical Medicine, ECOHOST, Room B124, Keppel Street, London, WC1E 7HT

I should like to thank Professor Chris Lawrence, at The Wellcome Centre for the History of Medicine at UCL, for reviewing and commenting on a draft of this paper. The research for this article was conducted whilst I was a Research Associate at The Wellcome Trust, supported by a grant from The Wellcome Trust.

\footnotetext{
${ }^{1}$ Alison Gordon, 'TB refugee "must be held in hospital", Mail on Sunday, 1998, 30 Aug., p. 15.

${ }^{2}$ Ibid.

${ }^{3} 306$ c447-8W, Hansard, 1998, 14 Feb.

${ }^{4} \mathrm{MH} 55 / 2281$, Removal of infectious persons to hospital under S.172 of the Public Health Act 1936: attempts to track down an itinerant tuberculosis patient 1956-63, London, Public Record Office.
} 


\section{Richard Coker}

to avail themselves of the medical care and skilled nursing which they obtain in a hospital. In a minority of instances where the patient or his family have at first opposed removal to hospital, knowledge of the powers of compulsory removal has been sufficient to ensure eventual compliance. ${ }^{5}$

In the 1930 s and 1940s the Ministry of Health concurred with this view that the powers of compulsory removal were seldom invoked; only one instance was reported in England in 1928, one in 1929, three in 1930, three in 1931, and no instances were reported in Wales during this period. ${ }^{6}$ In the 1960 s, detention was still only infrequently being resorted to. In Birmingham, for example, the council estimated in the late 1960 s that two detention orders had been issued during the previous decade. ${ }^{7}$ More recently, in the early 1990s, a survey of Consultants in Communicable Disease Control and Medical Officers of Environmental Health suggested that detention orders were issued at a rate of about one per year in England.$^{8}$ By the late 1990s, however, there was a suggestion that detention orders were being issued more frequently. During 1999 in London alone at least four orders for detention were issued, two of them for six months. ${ }^{9}$

Like policy responses to the mentally ill, some communicable diseases, such as tuberculosis, syphilis, and HIV, are particularly good lenses through which to view society. Because the state plays a role in both maintaining and protecting freedom, and in protecting its citizens from threats to their health, social tensions may be exemplified in responses to communicable diseases. Society's political and moral positioning in regard to this tension is embodied in its legislative response. In particular, legislation and its application to those with tuberculosis illustrate how society views those on the margins, from the homeless alcoholic to immigrants and felons. René and Jean Dubos recognized something of this special interrelationship in their 1952 book, The white plague: tuberculosis, man, and society, when they wrote of the disease and its connection with "the emotional and intellectual climate of the societies" in which it is found. ${ }^{10}$

The emotional climate of England and Wales was permissive in the 1960s. Yet it was, ironically, in 1968 that the 1925 civil safeguards protecting tuberculosis patients from arbitrary detention were repealed. Recently opened files at the Public Record Office shed some light on why this was done. This paper charts the course of legislation authorizing the civil detention of patients with tuberculosis and asks whether today's climate might be leading to abuses.

\footnotetext{
${ }^{5}$ A S MacNalty, 'A report on tuberculosis. Including an examination of the results of sanatorium treatment', London, HMSO, 1932, Special Report Series, No. 64.

${ }^{6} \mathrm{MH}$ 96/1031, Welsh Board of Health: registered files 1938-1948, London, Public Record Office. MH 55/133, Compulsory removal to hospital of persons suffering from tuberculosis: Local Acts 1934, London, Public Record Office.

${ }^{7}$ MH 154/491, Infectious diseases-notifications. Proposed amendments and draft consolidated regulations, London, Public Record Office.
}

\author{
${ }^{8} \mathbf{B}$ Kaur and $\mathbf{P}$ Bingham, 'Compulsory \\ removal to and detention in hospital in the case \\ of notifiable disease: a survey of public health \\ doctors', Public Health, 1993, 107: 199-204. \\ ${ }^{9} \mathrm{R}$ J Coker, 'The law, human rights and the \\ detention of individuals with tuberculosis in \\ England and Wales', J. Pub. Hlth. Med., 2000, \\ 22: 263-7. \\ ${ }^{10}$ René Dubos and Jean Dubos, The white \\ plague: tuberculosis, man, and society, Boston, \\ Little, Brown, 1952, p. vii.
}




\section{Detention of Tuberculous Patients}

\section{Detention and Safeguards against Abuse}

In January 1988, Sir Donald Acheson, the Chief Medical Officer for England, published Public health in England: the report of the Committee of Inquiry into the future development of the public health function. This was the result of an inquiry into the future development of the public health. Although this was only four years after the Law Commission had reviewed the existing public health laws and consolidated them into the 1984 Act, Public health in England suggested that the Public Health (Control of Disease) Act, 1984, should be revised with a view to producing a more up-to-date and relevant legislative backing to control communicable disease and infection. Acheson had noted that there was a

... lack of clarity about the role and responsibilities in [the field of public health which] derives from the complexity of the legislation and from a misunderstanding about its interpretation. The Public Health Acts comprise a complex body of legislation stretching back for more than a century. It is difficult to gain a coherent view of what is intended. ${ }^{11}$

In fact, powers of detention for infectious diseases were initiated in the Public Health Act 1875 (which, in addition to much else, consolidated and reaffirmed the 1848 Public Health Act). These Acts, despite their profound implications, did not generate much popular passion because they sought, by-and-large, to "regulate environmental conditions, not individual behaviour". ${ }^{2}$ But the 1875 Act did expand the state's authority in one important area. In relation to controlling individuals with contagious diseases, Section 124 specifically authorized for persons "suffering from any dangerous infectious disorder, and without proper lodging or accommodation ... . [to] be removed, by order of any justice, to such hospital or place at the cost of the local authority". Section 125 gave power to local authorities to remove individuals with dangerous infectious disorders and keep them in "hospital as long as may be necessary". In a sense these powers were a natural extension to the compulsory legislation introduced in the 1850s and 1860s to control infectious diseases. However, unlike the Public Health Acts, the Compulsory Vaccination Acts of 1853 and 1867 (which obliged parents to have their children vaccinated), and the Contagious Diseases Acts of 1864, 1866 and 1869 (authorizing the compulsory medical inspection of prostitutes for venereal diseases) generated considerable opposition from civil libertarians leading eventually to their repeal. The success of those advocating repeal, it has been suggested, arose because of the weaknesses of alliances between government and the medical profession and because of "deep internal divisions within both as to the propriety and prudence of health enforcement" ${ }^{13}$ factors which were not to the fore in regard to the Public Health Acts. Furthermore, as Dorothy Porter and Roy

\footnotetext{
${ }^{11}$ Donald Acheson, Public health in England: the report of the committee of inquiry into the future development of the public health function, London, HMSO, 1988.

${ }^{12}$ Howard M Leichter, Free to be foolish: politics and health promotion in the United States and Great Britain, Princeton University Press, 1991, p. 48
}

\footnotetext{
${ }^{13}$ Dorothy Porter and Roy Porter, 'The enforcement of health: the British debate', in E Fee and D Fox (eds), AIDS: the burdens of history, London, University of California Press, 1988, pp. 97-120, on p. 107.
} 


\section{Richard Coker}

Porter have argued, "by the last quarter of the nineteenth century the public was becoming acclimated to a new medical rationality that might involve the trimming of its liberties". ${ }^{14}$

Although the powers in Sections 124 and 125 of the 1875 Public Health Act appear draconian, offering little in the way of civil safeguards to those with "dangerous infectious disorders", clear concern was expressed for those with tuberculosis. The Act authorized the compulsory removal by order of a JP of an "infectious" individual to an isolation hospital in certain circumstances (principally for those individuals arriving by boat or ship) but in the Act it was expressly noted that "no provisions contained in any general or local Act of Parliament relating to infectious diseases shall apply to tuberculosis of the lung or proceedings relating thereto". The reasons for the exclusion of those with tuberculosis were in large part due to the endemic nature of tuberculosis, the fact that it crossed class barriers, that epidemics of acutely infectious diseases, in particular cholera, generated considerably greater immediate public and political anxiety, that the duration of tuberculosis might stretch to years, and that there was a concern that stigmatization of those with the disease, already a problem, might be aggravated. Indeed, George Kayne suggested that reluctance on the part of the authorities to detain those with tuberculosis was principally because of this risk of stigma, that "patients would be regarded as social lepers". ${ }^{\text {. }}$ Added to this there was still, in 1875 , seven years before Robert Koch's announcement that he had discovered the bacteria responsible for the disease, great scepticism by many surrounding its microbial causation. It was only by the late 1880 s that consensus emerged regarding the role microbes played in disease. Moreover, in 1875, the term "infectious disease" was still somewhat ill-defined. Although the notion of infectiousness had taken hold by the late 1870 s, the lack of that agreement that can be seen in the large number of alternative terms (infectious diseases, dangerous diseases, notifiable diseases, dangerous infectious disorders) used in legislation (often interchangeably) continued for some time. The 1880 s brought some clarity to the issue. In the Infectious Disease (Notification) Act, 1889, and the Infectious Disease (Prevention) Act, "infectious diseases" meant any of the following: smallpox, cholera, diphtheria, membranous croup, erysipelas, scarlatina or scarlet fever, and typhus, typhoid, enteric, relapsing, continued or puerperal fevers. Tuberculosis was not included.

A further source of reluctance to detain infectious individuals with tuberculosis during the nineteenth century probably came from local authorities. They were concerned that they might be legally bound to retain such people till they became non-infectious. This concern would have increased with passage of the Isolation Hospital Acts of 1893, 1901 and 1903. These resulted in county councils potentially being liable for accommodation expenses of patients with tuberculosis. ${ }^{16}$

By 1900, the mood (as well as the knowledge base), at least among some experts, was changing. For example, in 1901, Thomas Whiteside Hime, president of the

${ }^{14}$ Ibid., p. 109.

${ }^{16}$ Ibid., pp. 36-59.

${ }^{15}$ George G Kayne, The control of tuberculosis in England: past and present, London, Oxford University Press, 1937, p. 48. 


\section{Detention of Tuberculous Patients}

North-Western Counties Association of Medical Officers of Health, wrote in relation to the absence of provisions to remove and detain tuberculous individuals in Sections 124 and 125: "One would have thought a case of infectious disease occurring in a room occupied by one family would have been sufficient to authorize its removal to hospital. Parliament thinks otherwise." He went on: "Phthisis [that is, pulmonary tuberculosis] and some other forms of tuberculosis should certainly be included. They are infectious, terribly destructive, and undoubtedly far more controllable by ordinary preventive measures than scarlet fever, etc."17

A shift in attitude with regard to the destitute coupled with a belief in the merits of segregation was reflected in a 1908 editorial in the British Journal of Tuberculosis:

Every year an enormous number of consumptives pass into our workhouse infirmaries. The annual death-roll of these unfortunates affords merely a fractional indication of the great army of tuberculous derelicts dependent on charity and State support. By universal admission, our Poor Law system has been found sadly lacking, and with regard to no class has this failure been more conspicuous, deplorable, and inexcusable than in the case of the destitute consumptive.

\section{It noted that the}

period during which a consumptive may be considered to be infective varies greatly, but there is good evidence to show that three years may be accepted as a fair average. For the majority of these chronic cases the State does very little or nothing. The victims are left to struggle and to suffer, dragging into destitution and disease their families and friends, and only too frequently multiplying the evil by the propagation of delicate and tuberculously disposed children. The condition of large numbers of advanced and helpless consumptive cases is deplorable.

In raising concerns about the nature and social consequences of tuberculosis the editorial allied them to the fear of stigmatization and also to the perceived need for segregation:

Those who work among the consumptive cases of our metropolitan and provincial hospitals and sanatoria know well the dread which these patients have of the Union infirmary, and their absolute refusal in most cases to resort to Poor Law relief. No satisfactory advance towards the elimination of the Great White Plague can be effected until rational means are found for the effective segregation and proper care of these infectious consumptive cases for whom no other aid is possible than that which should, and must, be provided by the State. ${ }^{18}$

In 1912, Herbert de Carle Woodcock, a member of the council of the National Association for the Prevention of Consumption and Other Forms of Tuberculosis (NAPT), also captured the prevailing attitude of much of the medical profession: "Tubercle is in truth a coarse, common disease, bred in foul breath, in dirt, in squalor and the beautiful and the rich receive it from the unbeautiful poor." $\mathrm{He}$

\footnotetext{
${ }^{17}$ Thomas Whiteside Hime, The practical guide to the Public Health Acts, London, Baillière,

${ }^{18}$ Editorial, 'Tuberculosis and the poor law', Tindall and Cox, 1901, p. 96.
} 


\section{Richard Coker}

noted later in the same book: "Legislation has had much to say concerning hours of work and overcrowding of workshops; but it has little to say of physical dirt, and nothing of moral dirt and I hope to see the day when tubercle and alcoholism and allied diseases will be under rigorous inquisition." 19

The legislature lagged behind the medical profession in calls for restrictions on tuberculosis sufferers. The protections in the 1875 Act were reiterated in the 1908 Public Health (Tuberculosis) Regulations that noted specifically that

Nothing in these regulations shall have effect so as to apply or so to authorise or require a medical officer of health or a council or any other person or authority to put into force ... any enactment ... which subjects a poor person to any restriction, prohibition or disability affecting himself or his employment, occupation, means of livelihood, or residence on the ground of his suffering from pulmonary tuberculosis.

It was not until 1911 that the "army of tuberculous" patients could be counted (only mortality, not morbidity, from tuberculosis had previously been documented) and something of the magnitude of the problem known with any certainty. Through the Public Health (Tuberculosis) Regulations, 1911, it was made compulsory for doctors, intially, to notify patients with pulmonary tuberculosis receiving treatment in public institutions, and later that same year, compulsory notification was extended to all cases of pulmonary tuberculosis. The following year all cases of tuberculosis, pulmonary and extra-pulmonary, became notifiable. Around this time, in addition to being able to keep under surveillance the numbers of patients with tuberculosis (and as a consequence plan institutional and after-care demand) several local authorities, in response to demands such as de Carle Woodcock's, introduced powers to detain some patients.

The first authority to do so was St Helen's. In 1911, a clause was introduced to the local Corporation Bill which meant that the medical officer of the borough could, in certain circumstances, make application to a court for an order for "the removal of a person suffering from pulmonary tuberculosis to a suitable hospital or place for the reception of the sick, provided within the borough or within a convenient distance of the borough and for the detention and maintenance of such person therein for such period not exceeding 3 months as may be determined by such order". ${ }^{20}$ Other local authorities, such as Liverpool, Bradford, and East Ham, followed suit. ${ }^{21}$ Endorsing these local responses, in 1913 the Astor Committee, a Ministry of Health departmental committee, recommended that compulsory isolation be made available, in particular in instances where the patient's surroundings were thought to put others at risk of becoming infected..$^{22}$ Despite this, however, and perhaps reflecting the concerns that detention might be inappropriate and of uncertain effectiveness, clauses similar to that introduced by St Helen's were disallowed in bills

\footnotetext{
${ }^{19}$ Herbert de Carle Woodcock, The doctor and the people, 2nd ed., London, Methuen, 1912, pp. 184, 202-3.

${ }^{20} \mathrm{MH} 55 / 296$, Further powers as to removal of infected persons to hospital, London, Public Record Office.
}

\author{
${ }^{21}$ MH 55/133, op. cit., note 6 above. \\ ${ }^{22}$ Astor Committee, 'Final report', 1913, i, 8.
}




\section{Detention of Tuberculous Patients}

in several other locales (notably Sheffield in 1912, Barry in 1913, West Bromwich in 1913, and Chatham in 1923). ${ }^{23}$

By the 1920s the Ministry of Health, several local authorities, and much of the medical profession (including, in particular, several recognized tuberculosis authorities) were in favour of compulsory detention in certain circumstances. ${ }^{24}$ The earlier concerns of local authorities over the cost of caring for tuberculous patients had been realized by passage of the Public Health (Tuberculosis) Act, 1921, which imposed on county and county borough councils the duty of providing a scheme for the treatment of the tuberculous in their area including "sanatorium benefit", which had previously been available only to the insured or affluent. ${ }^{25}$ Under the 1921 Public Health (Tuberculosis) Act, local authorities in England and Wales became responsible for tuberculosis prevention and free treatment in their respective areas, and, as a consequence, were liable for care whether or not it was received voluntarily. Segregation of those suffering from tuberculosis was now believed to be an effective preventive measure and detention of some patients whom, it was preceived, posed a particular threat was deemed a responsible public health measure. Yet this approach was tempered by a loss of faith in eradication of disease-causing microbes as a concept. ${ }^{26}$ There was also concern about civil liberties at a time when the rights and duties of citizens were actively debated.

By 1925 , the powers to remove and detain individuals with notifiable diseases were provided by Sections 124 and 125 of the 1875 Act. These sections offered few protections for individual rights. But in 1925, in regard to tuberculosis, an additional clause (Section 62), similarly worded but with several important civil safeguards and compensations, was incorporated, despite some opposition, into the 1925 Public Health Act. The Lancet reported a House of Lords debate in which it was suggested that Section 62 should be left out because it "seemed to be likely to give rise to very considerable expense, to interfere with the existing hospitals, and to be of the nature of 'grandmotherly' legislation". In response, the government, through Lord Emmott, argued that the clause was "necessary to protect the public from infection. Pulmonary consumption was a highly infectious disease, and if the local authorities had not power to deal with it, it was possible for it to spread very considerably." He went on noting that

There were great safeguards in the clause ... its application was limited to patients whose surroundings prevented the adoption of proper precautions . . . it must be shown that serious risk of infection arose ... the period of detention was limited, and . . . an application could be made on behalf of the patient to the court for the rescission of the order at any time after six weeks from the date of the order. ${ }^{27}$

\footnotetext{
${ }^{23} \mathrm{MH} 55 / 296$, op. cit., note 20 above.

${ }^{24}$ John K Fowler, Problems in tuberculosis: administration, diagnosis, employment, settlements, London, Henry Frowde and Hodder \& Stoughton, 1923. Magnus S Patterson, The shibboleths of tuberculosis, London, John Murray, 1920.

${ }^{25}$ Kayne, op. cit., note 15 above, pp. 93-8.

${ }^{26}$ John Andrew Mendelsohn, 'From eradication to equilibrium: how epidemics became
}

complex after World War I', in C Lawrence and $\mathrm{G}$ Weisz (eds), Greater than the parts: holism in biomedicine, 1920-1950, Oxford University Press, 1998, pp. 303-31.

27 'Parliamentary intelligence. House of Lords, July 23rd. The Public Health Bill', Lancet, 1925, ii: $256-7$. 


\section{Richard Coker}

The Public Health Act, 1925, came into force on 8 September and the Lancet reflected that, "even contrary to his wish", an individual could be detained for three months and that "to safeguard the patient in such a case it is enacted that this power shall only apply where accommodation prevents the adoption of adequate measures against the spread of infection and where it can be shown that there is a serious risk to others". ${ }^{28}$

A number of safeguards were built in to the 1925 Act, therefore, to protect those with tuberculosis from over-zealous public health officials and arbitrary detention. First, detainees were given three days' warning that an order was going to be issued, which gave individuals time to mount a defence of their actions; second, detention was of limited duration (a maximum of three months, which with the 1936 Public Health Act could be extended on application for a further three months); third, there was an automatic built-in codified process of review; fourth, applications for the order to be rescinded could be made from a specified time (six weeks after the issuance of the order); and fifth, orders for detention had to be made in person, not ex parte. Other sections, without these civil liberty safeguards, provided for other "dangerous infectious diseases". It was these safeguards for tuberculous patients that were, in 1968, removed and other sections of the Act, applicable to notifiable diseases without the benefit of these protections, were extended to cover tuberculosis.

This concern for tuberculous individuals' rights and reticence in using detention as a public health tool in 1925 persisted through the 1930s. In 1936 a new Public Health Act was passed. Sections 124 and 125 of the 1875 Act were repealed and powers of detention were provided through Sections 169 and 170 of the new 1936 Act. (The wording in Sections 37 and 38 of the 1984 Act reproduces almost exactly Sections 169 and 170 of the 1936 Act - no safeguards have been added.) Section 172 of the 1936 Act, with the same in-built safeguards, replaced Section 62 of the 1925 Act. In practice through the 1930s, as Linda Bryder has noted, "policies involving compulsion and interference in personal liberties [of those with tuberculosis] were shied away from in favour of policies involving persuasion". ${ }^{29}$ This approach arose in part because eradication of disease was perceived as being impractical. Furthermore, diagnosis was often uncertain, and frequently took a long time; most institutions favoured those with early disease rather than chronic infectious cases: and there were too few beds. In 1941, for example, it was estimated that there were 77,000 cases of infectious tuberculosis in England, and only 28,087 beds. ${ }^{30}$ In addition, this persuasive approach also reflected part of the wider debate relating to the meaning of good citizenship, social responsibility, and a profound concern for civil liberties. ${ }^{31}$ ii: $556-7$.

28 'The Public Health Act, 1925', Lancet, 1925,

${ }^{29}$ Linda Bryder, Below the magic mountain: a social history of tuberculosis in twentieth-century Britain, Oxford, Clarendon Press, 1988, p. 130.

${ }^{30} \mathrm{P}$ Edwards, G Jessel, D P Sutherland, F R G Heaf, and J B McDougall, 'The rehabilitation and care of the tuberculous: the fifth report of the employment committee of the Joint Tuberculosis Council', Tubercle, 1942, 23: 1-49.

${ }^{31}$ Mathew Thomson, 'Constituting citizenship: mental deficiency, mental health and human rights in inter-war Britain', Clio Medica, 2000, 60: 231-50. 


\section{Detention of Tuberculous Patients}

\section{Loss of Civil Safeguards}

The period between the mid-1950s to the early 1970s has been termed "the new age of cultural change", an era viewed by many as profoundly different from previous ones. ${ }^{32}$ People were living longer, infectious diseases had been either eradicated or were successfully controlled. But more than this, there had been a sea-change in social policy with a greater concern for equality than before, and a questioning of the state's right to interfere in matters of personal concern which resulted in challenges to paternalistic and authoritarian power. Yet in 1968, at perhaps the peak of the liberal permissive era when concern for the vulnerable, for example, had resulted in the repeal of draconian mental health legislation and a greater emphasis being placed on assessments of risk (to others and themselves) and on providing the mentally ill with greater legal protections, the in-built civil safeguards for tuberculosis patients were removed; Section 172 was repealed in its entirety. Why was this?

Several issues, including a rise in immigrant-associated tuberculosis and the spectre of drug-resistant disease, were causing some raised eyebrows at the Ministry of Health and the Joint Tuberculosis Council. In the 1960s, tuberculosis rates in recent arrivals to Britain from the new Commonwealth were high and as the number of immigrants from the Commonwealth rose (in particular from the Indian subcontinent, the West Indies, and Africa) so too did the associated proportion of tuberculosis cases. In 1965 while immigrants formed 4 per cent of the total population of Britain, they accounted for 16.5 per cent of tuberculosis notifications; the incidence of tuberculosis amongst Pakistanis was 26 times that of the local population, amongst Indians 12 times, amongst other Asians 6 times, and amongst West Indians 3 times that of British-born residents. ${ }^{33}$ This increase of tuberculosis in immigrant groups touched a raw nerve. Immigration, race relations and "inner city" problems were high on the political agenda and sensitive. (Files relating to tuberculosis in immigrants for 1961 and 1962, for example, remain closed.) ${ }^{34}$

Although the widespread availability of effective treatment had facilitated a change in the public image of tuberculosis by lessening the dread of the disease, "ostracism and prejudice" were still common, and perhaps more so than earlier in the century, as shown by a 1960 Joint Tuberculosis Council survey. ${ }^{35}$ Indeed, one might conclude that, in the light of recent therapeutic advances, the rise in living standards, and the apparent conquest of infectious diseases, the 1960s was a period when public intolerance of disease grew.

The fear and stigma attached to tuberculosis, the concerns of the medical

${ }^{32}$ Arthur Marwick, British society since 1945 , London, Allen Lane, 1982.

33 'Tuberculosis among immigrants to England and Wales: a national survey in 1965 . A report from the research committee of the British Tuberculosis Association', Tubercle, 1966, 47: $145-56$.

${ }^{34} \mathrm{MH} 55 / 2633$, Medical examination of immigrants, including Commonwealth immigrants:
Commonwealth Immigrants Act 1962; tuberculosis and the question of $X$-ray examinations; correspondence and policy 1961-62, London, Public Record Office.

${ }^{35}$ The Joint Tuberculosis Council, 'Tuberculosis: report on the reception of expatients in respect of re-employment and superannuation, life assurance and emigration', Tubercle, 1960, 41: 370-9. 


\section{Richard Coker}

profession over drug resistance, ${ }^{36}$ the broader political dimensions to immigrantassociated tuberculosis, and the freeing up of resources (consequent upon effective treatment and earlier diagnosis because of mass radiography in the 1950s) created a climate in which the removal of civil rights in this defined sphere was perhaps acceptable in the pursuit of public health protection. In this climate it was, however, two issues which specifically resulted in a change in the legislation. The first, the case of one individual, prompted an assessment of the issues surrounding the use of detention, and ultimately contributed to the revision of the laws relating to the detention of uncooperative individuals with tuberculosis. ${ }^{37}$ The second was the wish to remove an anomaly introduced in 1936. If an order was made for removal to hospital of a tuberculosis patient, the local authority or county council had to bear the cost of the detainee's removal and maintenance-subsection (5) of Section 172 meant that dependents of individuals detained were offered financial support whereas those of voluntary patients were not, and, furthermore, this support came from local purses. ${ }^{38}$

\section{The Case of Josef Bojasinskas}

Josef Bojasinskas was a 38-year-old "stateless alien" who had formerly been a Lithuanian merchant seaman. He had repeatedly, in the late 1950 s, been admitted for treatment for pulmonary tuberculosis and prematurely discharged himself. Indeed, the Home Office and the National Assistance Board were prevailed upon by the Ministry of Health to help this "menace to the community", to find him, and issue him with a detention order (expulsion from the country was considered, but rejected). ${ }^{39}$ According to recently opened records, Bojasinskas appears to have been an inpatient in twenty-four hospitals over a period of two years, at a time when his "sputum was teeming with tubercle bacilli". ${ }^{40}$

Considerable debate took place over a three-year period in the Ministry over what course of action should be taken to control Bojasinskas. Initially, although it was recognized that "under Section 172 of the Public Health Act, 1936, powers do exist for the removal of persons suffering from infectious tuberculosis, and for their detention in hospital for a time ... it has never been considered expedient or politic to operate this section of the Act". One reason given for the lack of enthusiasm for resorting to Section 172 was that "although the patient can be got into a Sanatorium, there is no power to give treatment, and such men, being fundamentally asocial, are

\footnotetext{
${ }^{36}$ M B Lurie, Resistance to tuberculosis: experimental studies in native and acquired defensive mechanisms, Cambridge, MA, Harvard University Press, 1964.

${ }^{37}$ MH 55/2281, op. cit., note 4 above. MH 55/ 2758, Joint Tuberculosis Committee. Papers, correspondence, stats. 1963-65, London, Public Record Office. MH 55/2634, Medical examination of immigrants, including Commonwealth immigrants: Commonwealth Immigrants Act; tuberculosis and the question of X-ray
}

examinations; correspondence and policy 1963, London, Public Record Office.

${ }^{38}$ MH 154/487, Infectious diseases: Public Health Acts 1936 and 1961; consideration of amendments, London, Public Record Office.

${ }^{39} \mathrm{MH} 55 / 2281$, op. cit., note 4 above.

${ }^{40} \mathrm{MH} 55 / 2281$, op. cit., note 4 above. Medical correspondent, 'Danger from the anti-social TB sufferers: one man's 24 hospitals in two years', Manchester Guardian, 1959, 11 May, p. 2. 


\section{Detention of Tuberculous Patients}

difficult to manage and tend to upset the other patients and the discipline of the institution".41

This irresolution did not last long. By mid-1957, eight months after the Ministry had first been told of him, officials were collaborating with the Home Office to track him, but were concerned that he might elude them: "We do not, of course, want any steps taken at this stage which might arouse the man's suspicions that we are 'after him' in any way as he seems to have a knack of disappearing as soon as any attempts are made to persuade him to be hospitalized." A month later there was the serious concern that Bojasinskas posed a significant public health risk, that "the presence of such an individual is sufficient to cause a minor epidemic of pulmonary tuberculosis wherever he goes". Others were, however, more circumspect: "In the case of a nomad, such as [Mr. Bojasinskas], it might be difficult to establish an acute degree of risk, since this type of man is essentially asocial."42

The tempo and tone of debate within the Ministry changed substantially after Sir Leslie Plummer, MP for Deptford, eventually raised the concerns of one of Bojasinskas' physicians in the House of Commons:

One man who uses that hostel is an infectious tubercular sufferer, if that is the right phraseology. He has tuberculosis, and he can transmit it freely and easily to other people. Now and again he goes into hospital for some treatment and is kept alive as a result. Then he gets bored with it and leaves the hospital, where nobody can keep him. He goes to a cinema or into a public house and drinks from glasses which are then presumably used by other people. Then he goes back to the L.C.C. [London County Council] lodging house and sleeps in dormitories with other people. Then he disappears altogether; no one can find him; and then suddenly back he comes again.

This man is a walking menace to the health of the people with whom he is in contact. Heaven knows how many he has already infected and put on the National Health Service ... I took it up with the right hon. and learned Gentleman the Minister of Health. He told me, and I paraphrase what he said, "It is perfectly true that there is a law under which this man could be confined, but nobody ever does anything about it, so we cannot do anything." So this man is free to roam about the country. ${ }^{43}$

Sir Leslie had floridly highlighted the perceived public health risk posed by his constituent's patient (hinting even at the possibility of transmission through routes other than inhalation). He had also suggested that the patient had been spending time in congregate settings, despite being "asocial". (In the eyes of the Ministry, Bojasinskas graduated from being asocial to antisocial at this time.) Although the concerns raised by Plummer were of a practical nature, not least the lack of detention facilities, it was the legal not the residential concerns which were resolved with the passage of the Health Services and Public Health Bill a few years later.

Following the issue being raised in the House of Commons, there was frustration at Ministry level that the framing of the 1936 Act inhibited use of Section 172: "The difficulty of using the Public Health Act provisions against an unco-operative person is that he must be given three days' notice of the court hearing (which enables him

${ }^{42}$ MH 55/2281, op. cit., note 4 above.

${ }^{43}$ 1256, Hansard, 1958, 5 March. 


\section{Richard Coker}

to disappear)." By mid-1958, two years after he had first come to notice, the Ministry had concluded that "it seems desirable for the public good that Josef Bojasinskas should not be roaming about at large", and attempts were made to track him when he appeared to the National Assistance Board (NAB) to collect money. The assistance of the NAB was given covertly for fear of undue publicity. Officials at NAB suggested that "it would probably be as well to keep the Board's name out of the picture as the source from which any information comes into your possession."

With NAB's assistance, the Ministry of Health tracked Bojasinskas, "this itinerant germ carrier", through Orpington, Maidstone, Fulham, and Woolwich. In addition, the services of the Registrar General of Shipping and Seamen were considered because it was felt he might join a ship. However, by late 1958 several at the Ministry were becoming disheartened in the chase. One commented: "I have a feeling we are not going to get anywhere with this man", ${ }^{45}$ and, although they continued pursuing him, other problems were occurring. In particular, he kept returning to London, which was not covered by the 1936 Act. (Other courses of action were considered, but not acted upon, including returning him to Lithuania, detaining him under Section 47 of the 1948 National Assistance Act, and issuing criminal proceedings in order to imprison him for an alleged indecent assault on a nurse.) The case of Josef Bojasinskas was concluded when he finally consented to a left upper lobectomy and subsequently received several months inpatient treatment after which he was finally discharged in late 1959.

Following the Bojasinskas case, the Ministry maintained an interest in changing the legislation to facilitate the use of the public health police powers. The first issue which needed to be resolved was the extension of the powers to include London. In discussing at sub-committee level their report on Tuberculosis in vagrants and common-lodging houses, the Joint Tuberculosis Council addressed the issues of reluctance of some individuals to comply with treatment and lack of legislative recourse in London when attempts to persuade failed: "Vagrants and people living in common lodging houses were an important group, since it was here that a much larger proportion [of individuals with tuberculosis] was to be found, and the number of patients developing resistant strains of tubercle bacilli was likely to be high." They went on:

The general impression is that they are reluctant to submit to any discipline or to a hygienic way of life. They avoid officialdom as far as possible ... Among the causes for the difficulties are the low grade of intelligence of a large proportion of these men and the fact that they have followed an unsettled way of life for a long time. They are content with this and are ready to "sleep rough" rather than risk the loss of their "freedom" and their ability to wander at will ... Once a diagnosis of tuberculosis has been made it is often difficult to persuade this type of patient to accept treatment.

The committee concluded:

Vagrants and inmates of lodging houses who are suffering from tuberculosis therefore present many problems, and have a high rate of incidence of the disease. Nevertheless, these facts do

${ }^{44} \mathrm{MH} 55 / 2281$, op. cit., note 4 above.

${ }^{45}$ MH 55/2281, op. cit., note 4 above. 


\section{Detention of Tuberculous Patients}

not necessarily make them a dangerous group in our society. The numbers are becoming less. There are few if any in most towns and districts, but in a small number of large cities the problem is considerable. Only a small proportion can be brought to treatment and persevere to success. These aspects counterbalance the facts that some of them have chronic almost untreatable disease and of these a high proportion carry bacilli resistant to the standard drugs.

The Council suggested in its report that "The powers of ordering compulsory detention ... could profitably be used more often, and the [1936 Public Health] Act should be made to apply in the area controlled by the London County Council as well as in England and Wales." 46 The Council lobbied for a clause to be inserted "to bring the new Greater London Authority in to line with the rest of the country as regards the operation of Section 172" and in the London Government Act, 1963, a clause which achieved this was duly inserted. ${ }^{47}$

\section{An Anomaly Remedied}

As early as 1942 concerns had been raised that an injustice existed whereby the dependents of those with tuberculosis who willingly went to hospital did not receive assistance whereas those who were detained did. ${ }^{48}$ In the drafting of the Health Services and Public Health Bill it was initially envisaged that this anomaly, which resided in sub-section (5) of Section 172, would be repealed. The other sub-sections, which provided safeguards including a limitation on the period of detention to three months or less (sub-section 1), the fact that continued detention periods (after three months) required further court orders (sub-section 2), that three days' notice be given to the patient (sub-section 3), and that at any time after six weeks from the issue of an order an application to rescind the order could be made (sub-section 6). None of these safeguards, as noted above, were available to those detained for other notifiable diseases (under Sections 169 and 170 of the 1936 Public Health Act).

In 1963 civil servants at the Ministry of Health contemplated removing only subsection (5). Indeed in early notes on the Bill it was suggested that

For an infection of major severity but short duration prompt action on the order of a Justice (acting ex-parte if necessary) is the only satisfactory way of dealing with the situation. For a disease such as pulmonary tuberculosis where there is less urgency, application to the court (with right of appeal and provisions for renewal of a detention order) is more appropriate.

Two years later, however, the Ministry was "incline[d] to repeal the whole section" but not permit ex parte applications for orders. No mention was made of detention periods; it was envisaged that "these days quite short periods were likely to be laid down", implying that with effective treatment the duration of infectiousness was likely to be short and prolonged periods of detention would be unnecessary. ${ }^{49}$

The Ministry consulted with several bodies informing them of the proposals. These included the British Medical Association (BMA), the Association of Municipal Corporations, the County Councils Association, and the Society of Medical Officers

\footnotetext{
${ }^{46} \mathrm{MH} 55 / 2758$, op. cit., note 37 above.

${ }^{47}$ MH 55/2756, Joint Tuberculosis Council, London, Public Record Office.
}

\footnotetext{
${ }^{48} \mathrm{MH} 96 / 1031$, op. cit., note 6 above.

${ }^{49} \mathrm{MH} 154 / 487$, op. cit., note 38 above.
} 


\section{Richard Coker}

of Health. No institutions questioned the removal of the civil safeguards. Indeed, two suggested removal of further safeguards. The Association of Sea and Air Port Health Authorities, and the Society of Medical Officers of Health both requested that "the authority to seek ex parte applications should not be removed". Whether this stance originated because of the Bojasinskas case, in which both institutions were involved, was not made clear in the letters. The BMA, responding nine months later, welcomed the proposals, and on being told that ex parte provisions were to be retained did not comment any further. ${ }^{50}$ The Ministry complied with the requests to remove this further safeguard and in the draft bill it was proposed that Section 172 be repealed in its entirety.

During the passage of the Bill (described by one MP as a "dog's breakfast" of a bill), which was principally concerned with paybeds in NHS hospitals, the manufacture and supply of drugs, and health centres, no mention was made in either the Commons or the Lords of the removal of the safeguards encompassed in Section 172. It was only in Committee that these issues were raised. During passage of the Bill, perhaps reflecting a lack of awareness that changes to legislation were being put forward, a lack of concern that civil safeguards were being removed, or a belief that the newfound authority would be used wisely, no mention of the changes was made in the pages of either the British Medical Journal or the Lancet.

At the committee stage of the Bill the Conservative Member of Parliament Tim Fortescue asked:

If the purpose of this Clause is ... simply that Section 172(5) of the 1936 Act should be repealed then why not delete just that subsection of Section 172 of the 1936 Act instead of deleting the entire Section? ... [I]f a sufferer from tuberculosis knows that if he co-operates and makes a real effort to get well he can be kept there [in detention] for only three months unless another order is given. Under the other provisions of the 1936 Act, people can be kept in hospital indefinitely without their case being reviewed and without another order being necessary ... I should like to know why this distinction between tuberculosis and other very infectious and notifiable diseases has been removed...

In other words Fortescue was asking why the whole section, with all its civil safeguards, was being repealed when the Labour administration was highlighting only the need to remedy an anomaly whereby the families of those detained were supported but the families of those who entered hospital voluntarily for treatment were left unsupported. The MP went on: "In the preamble, dealing with Clause 64, we read: 'Clause 64 repeals the provision in the Public Health Act, 1936.' And adds, 'protection of the public health can be satisfactorily achieved in other ways.' Could we know what the Parliamentary Secretary intends by those 'other ways'?'

The government spokesman responded, somewhat disingenuously: "I am aware of the disquiet, but as we have these residual powers in other legislation, we will have the necessary power which the hon. Gentleman fears that we are giving up."

Fortescue responded by suggesting that the explanation was

... not good enough. The Parliamentary Secretary did not answer any of my questions. Why

${ }^{50}$ MH 154/487, op. cit., note 38 above. 


\section{Detention of Tuberculous Patients}

throw out the whole baby with this small amount of bath water? Would not that be much better than throwing out the whole Clause and then relying on regulations, especially as the rest of the Clause has its value? Secondly, does the Parliamentary Secretary believe that this three months' limitation can be removed when it has been of value? Thirdly, what are the other ways in which tuberculosis can be dealt with, as mentioned in the Preamble?

The Parliamentary Secretary merely responded by saying: "We believe that within those powers [sections 169 and 170 which remained on the statute books] we have all the required defence and precautions of Section 172."

Despite some persistent questioning from Tim Fortescue, the question of why the safeguards were removed was never answered and the issue was never fully addressed in an open forum. ${ }^{51}$ The Labour government of the day removed earlier civil safeguards without any public debate, at the height of the liberal era, and without any clear reasons being given. This was done with the assumption that the powers would only infrequently be resorted to, that only short periods of detention would be ordered, and without any system of monitoring to ensure the powers were not being abused.

\section{Conclusion}

Since 1968 several bodies have looked at the laws governing public health. A consolidation exercise by the Law Commission, which resulted in public health legislation being redrafted in the 1984 Public Health (Control of Disease) Act, did not introduce new measures but simply brought together, in one statute, legislation which had been enacted gradually over the course of the previous one hundred years. No consideration was given to reintroducing greater civil safeguards for individuals with tuberculosis.

Within only four years of the Law Commission's consolidation exercise and the resultant 1984 Act, it was noted in the Chief Medical Officer Sir Donald Acheson's report, Public health in England, that "Some of its provisions now seem a little dated". 52 Acheson's consultation document was intended to provoke public debate with the document itself considering "the future development of the public health function, including the control of communicable diseases".

In regard to public health legislation the report concluded that "It is difficult to gain a coherent view of what is intended ... The fact is that these Acts now have little relevance to the majority of work actually undertaken in this field by either health or local authorities, although of course, the powers they confer will need to be retained for use in exceptional circumstances." The committee recommended that the Public Health (Control of Disease) Act, 1984, should be revised "with a view to producing a more up to date and relevant legislative backing to control of communicable disease and infection". Furthermore, the report noted that any revision

\footnotetext{
51 'Parliamentary debates, official report', House of Commons, Standing Committee D: Health Services and Public Health Bill, eleventh sitting, 1968, 27 Feb.
}

\footnotetext{
${ }^{52}$ Public health in England, op. cit., note 11 above.
} 


\section{Richard Coker}

"will need to look closely at the powers currently ascribed to 'proper officer', [and] to establish whether these are needed at all".

In response to Public health in England a review of infectious disease law was initiated by the Department of Health. This resulted in a consultation document in 1989 and a call for views related to revision of the law, including Sections 37 and $38 .{ }^{53}$ In reviewing these sections the Department was clearly aware of some of the possible shortcomings of the current legislation. The review noted the lack of protections of individual rights in comparison with the 1944 National Assistance Act (which has itself been criticized for offering too few safeguards). ${ }^{54}$ Specifically, the Department noted that, under current legislation, no notice of application need be given, oral evidence was not required, a full court hearing was unnecessary, there was no limit on the period of detention ordered, and there was no codified right of appeal. Views were invited on the question, "How could individual rights be protected against abuse of infectious disease control orders?" 55 The responses have not been made public.

Since the consultation exercise finished in January 1990, in which more than 500 contributions were collected, little has been done. It is currently the opinion of the Department of Health that "there is insufficient parliamentary time to carry out a major revision of the Public Health Act, 1984". ${ }^{56}$

Yet revision of the laws of detention is clearly needed. Since 1968 public anxiety regarding tuberculosis, and in particular drug-resistant disease, has increased. New York witnessed an epidemic in the early 1990s which resulted in more than $\$ 1$ billion being spent on a public health response; the World Health Organization, in 1994, called tuberculosis a "global emergency"; and London has seen a rise in tuberculosis notifications and drug resistant cases. ${ }^{57}$ Calls for more "sticks" in ensuring compliance have been heard, and these need to be tempered with protections from abuse. ${ }^{58}$

Allied to calls from professional groups for greater use of "sticks" has been, as in the 1960s, growing public anxiety fuelled by a media which associates anti-social behaviour or immigrants with disease. In 1959 the Manchester Guardian, under the headline "Danger from the anti-social T.B. sufferers: One man's 24 hospitals in two years", highlighted the alarm of doctors at the threat posed by the "anti-social behaviour of certain sufferers from pulmonary tuberculosis". These public health doctors were calling for greater powers to detain such individuals. Over the past two years headlines such as the Daily Mails "Brutal Crimes of the Asylum Seekers"

\footnotetext{
${ }^{53}$ Department of Health, 'Review of law on infectious disease control: consultation

document', London, Department of Health, 1989.

${ }^{54} \mathrm{~S} \mathrm{~J}$ Hobson, 'The ethics of compulsory removal under Section 47 of the 1948 National Assistance Act', J. Med. Ethics, 1998, 24: 38-43.

${ }^{55}$ Department of Health, op. cit., note 53 above.

${ }^{56}$ Personal communication, Department of Health, 8 July 1999.

${ }^{57}$ T R Frieden, P I Fujiwara, R M Washko, and $M$ A Hamburg, 'Tuberculosis in New York
}

\author{
City-turning the tide', $N$. Engl. J. Med., 1995, \\ 333: 229-33. World Health Organization, 'TB-a \\ global emergency. WHO report on the TB \\ epidemic', Geneva, World Health Organization, \\ 1994. A Hayward, 'Tuberculosis control in \\ London: the need for change. A report for the \\ Thames Regional Directors of Public Health (A \\ discussion document)', London, NHS Executive, \\ 1998. \\ ${ }^{58} \mathbf{P}$ Ormerod, 'More carrot or more stick or \\ both?', Thorax, 1999, 54: 96-7.
}




\section{Detention of Tuberculous Patients}

reset the tone. ${ }^{59}$ And when the Evening Standard's front page is emblazoned with headlines such as “ $£ 250,000$ Scandal of AIDS Man Britain Can’t Expel”, followed by the assertion that the "illegal immigrant from Brazil" concerned has "highlycontagious tuberculosis [and] is free to wander London's streets" then the connection of the threat from infectious diseases with immigrants heightens public anxiety. It becomes tempting for public health officials to apply inadequate laws to allay public fears.

Over the past decade a shift in attitudes amongst public health authorities has occurred. In the 1960 s public health concerns revolved around imminent threats to society, and this was reflected in legislation which enabled the constraint of those with communicable diseases and those who were mentally ill, that is those who posed an immediate threat. The increase in concern about drug resistant disease (consequent upon poor compliance with treatment) has resulted in public health control being increased through the whole of the period of treatment (which can last for six months or more).$^{60}$ This has meant a shift, or broadening, of concern from imminent threats to concerns about future, and largely unquantifiable, threats. ${ }^{61}$

Many in London (and indeed, elsewhere in the world) are looking across the Atlantic, to New York, to draw lessons from the success of the TB programme there. $^{62}$ In New York the anxiety over the tuberculosis epidemic was reflected in greater use of coercion to ensure compliance with treatment, and also a re-drafting of public health regulations such that non-infectious individuals could be detained "where there is substantial likelihood ... that he or she can not [sic] be relied upon to participate in and/or to complete an appropriate prescribed course of medication for tuberculosis". ${ }^{63}$ This shift in emphasis, away from an assessment of threat to assessments of compliance, was allied to changes which made explicit the incorporation of safeguards to protect individuals from abuse. ${ }^{64}$ These protections do not exist in England and Wales.

In October 2000, the European Convention on Human Rights was incorporated into British law under the Human Rights Act. Sections 37 and 38 of the 1984 Public Health Act fail to stand up to scrutiny under this standard and revision is necessary (as was explicitly acknowledged a decade ago). ${ }^{65}$ It is ironic that, in an age when state authority was questioned, fewer protections which would stand up to contemporary

${ }^{59}$ David Williams, 'Brutal crimes of the asylum seekers', Daily Mail, 1998, 30 Nov., pp. 1, 4-5.

${ }^{60}$ A K Hurtig, J D H Porter, and J A Ogden, 'Tuberculosis control and directly observed therapy from the public health/human rights perspective', Int. J. Tuberc. Lung Dis., 1999, 3: $553-60$.

${ }^{61} \mathbf{R}$ J Coker, 'Uncertainty, civil liberties, and public health', Br. med. J., 1999, 318: 1434-5. R J Coker, 'Carrots, sticks and tuberculosis', Thorax, 1999, 54: 95-6.
${ }^{62}$ M Dalziel, S Atkinson, G Duckworth, M McNichol, and A Hayward, 'London's problems', Br. med. J., 1988, 16 Sept., electronic responses, see website: www.bmj.com/cgi/eletters/317/7159/ 616\#EL2. 1993.

${ }^{63}$ New York City, N.Y., Health Code 11.47,

${ }^{64}$ Richard J Coker, From chaos to coercion: detention and the control of tuberculosis, New York, St Martin's Press, 2000.

${ }^{65}$ Coker, op. cit., note 9 above. 


\section{Richard Coker}

human rights standards were drafted, while in an era which, in the popular imagination, stands for liberty, individuality, and concern for the vulnerable, those safeguards were rejected and people already on society's margins were put at risk of arbitrary detention. 